\title{
Oil Companies and Host Community: A Probable Scenario for Reciprocal Empowerment
}

\author{
V. T. Jike \\ Department of Sociology and Psychology, Delta State University, P.M.B.1, Abraka, Nigeria \\ E-mail: jikevt@yahoo.com
}

KEYWORDS Conflict Resolution. Environmental Degradation. Holism. Peace Building. Poverty. Structural Functionalism. Synergy. Youth

\begin{abstract}
The paper is an incisive theoretical overview of the continuing conflict between oil companies and host communities in the Niger-Delta of Nigeria. It examine the contending issues around the substantive functions of oil companies and the latent consequences of environmental degradation which has remained a constant source of friction between oil companies and host communities. The paper adopts structural functionalism or holism as a theoretical model for understanding and creating a threshold for peace in the Niger Delta. The methodology adopted for this paper is rather crypt and largely ethnographic, involving long drawn interviews and non-participant observation of both oil workers and indigenes of the host community. Finally, the paper fosters synergy and recommends a scenario for reciprocal empowerment between oil companies and the host community in the Niger-Delta of Nigeria.
\end{abstract}

\section{INTRODUCTION}

Several scholars have highlighted the continuing conflict between oil companies and host communities in the Niger Delta (Vosad 1999; Akoroda 2000; Jike 2001, 2002a, 2002b, 2004). Part of this conflict has been painstakingly traced to the vast environmental degradation and consequent social disequilibrium that have trumped up several paradoxes including large-scale unemployment in the midst of vast resources. Jike (2004: 688) has examined some of these paradoxes and unequivocally stated that "the anxiety and expectations surrounding the discovery of oil have waned because the general livelihood of the people has not been positively affected by the discovery of oil". Jike (2004: 688) has further argued that, the multiplier dividends that should accrue from the sales of oil are neither here nor there. More significant and rather germane to the theme of this article is the spate of activism, which are reactions to the steady environmental degradation of the Niger-Delta as a result of oil prospecting activities. Part of this activism has metamorphosed into a resilient subculture of youth violence and rebelliousness, which are themselves clear signals of social disequilibrium that is inimical to the development process.

Part of the thrust of this paper is to move beyond the dialectics to a much more fundamental and holistic approach to the unfolding events in the Niger-Delta. This approach may stoke oil companies and host community synergy and encourage reciprocal empowerment between these two important stakeholders in the NigerDelta.

\section{Holism and the Interconnectedness of All Parts of the System}

The functionalist school or more aptly, structural functionalism emerged as an alternative conceptual framework to unilineal evolutionism of pre-20 $0^{\text {th }}$ century Europe. As Modo (1995: 40) rightly noted "at the beginning of the twentieth century, British anthropology started to reject the evolution framework and replace it with a model of society as a living organism. They used the concepts - structure and function. The functionalist school if one might refer to it as such is largely represented by the pioneering work of Bronislaw Malinowski (1884-1942) and Radcliffe-Brown (1881-1955). Although they viewed culture from different perspectives, there was consensus between them that the functions of cultural traits was its ability to meet the needs of members of society. While culture attempts to satisfy the biological and composite needs of human kind, it also provokes derived needs to sustain itself. This tenor of structuralist argument has re-echoed in the works of latter-day proponents of the structuralist tradition like Pfeiffer (1977), Ember (1977) etc. Emile Durkheim, the French sociologist has even gone further to attach a function to Bizzare criminal tendencies. Suffice it to say however that the structuralist see every cultural 
trait, social institution, etc. as serving a function to stabilise the system to maintain the status quo in accord with the biological principles of homeostasis. It is this latter structuralist characteristic of functions and dysfunction or more aptly, manifest and latent functions that are relevant to the thrust of this paper. We shall attempt to critically outline the manifest and latent functions of oil companies and how these meet expected corporate obligations to host communities.

\section{Manifest Functions and the Corporate Challenges of Oil Companies}

The production of crude oil and the marketing of gas products remain the overriding function of oil companies in Nigeria. This objective has been sustained by the global attraction for Nigeria's crude. The closing of the Suez Canal in the 1960s and the resurgent middle East crisis wittingly made Nigeria's crude oil preferable to European countries. The low sulphur content of Nigeria's oil $0.3 \%$ for API was also a major factor in its popularity.

More oil fields have been explored and the operational space for most oil companies have been expanded to increase the overall output and value of exportable crude oil. However, problems continue to bedevil the oil industry. Problems of a political kind especially those relating to a proposed dichotomy between onshore/offshore revenue accruals pitched the government against host community activist for a long time. The euphoria of globalisation and the strategy of internal re-organisation and downsizing have created grave industrial relations challenges that have repeatedly led to strike actions and the threat of closure by some oil companies. It is instructive to know that indigenous staff of oil companies in Nigeria have begun earnestly to question the avowed social responsibility of oil companies to host communities. Oil companies have also had their operational activities disrupted as a result of pipeline vandalisation, induced spillages and persistent youth restiveness especially in the Niger-Delta. It is, perhaps, pertinent to note that petroleum oil especially the issue of appropriate pricing has become contentious both economically and politically. In 2004 alone, Nigerians have expressed their displeasure with government's arbitrary oil price increases by staying back at home rather than going to work.

Petroleum oil has occupied a central position in the people's perception as the predominant revenue earner for the Federal Government of Nigeria. Almost $90 \%$ of the country's foreign exchange earnings together with budgetary allocations are predicated on petroleum oil. As the seventh world exporter of crude oil, Nigeria has not fared well in the management of the accruals from the petroleum trade. As Olatubosun (1975) aptly noted: It was clear by 1967 that there were a lot of structural contradictions in the Nigerian economy. Rural poverty existed alongside prevailing urban affluence; increasing education existed side by side with increasing unemployment, surplus land, hungry people.

Wolf (1983: 3) was even more forthright when he lamented that, had the oil resource been properly managed it could have eased Nigeria's transition as a developing nation; as it turned out, oil development induced a false euphoria, prolonged and deepened Nigeria's dependence on expensive imported commodities, distorted the economy and society towards dualism and disunion, and undermined confidence in her ability to raise a modern economy on her own resource. Resource was converted to waste, benefit to burden.

It is perhaps instructive to note that the lopsided pattern of industrial development in Nigeria has come under severe attack. One of the many critics of this peculiarly lopsided development strategy is Eteng (1981), who noted, for example, that Nigeria's gigantic plans were being implemented under the most unfavourable socioeconomic and political conditions in which the nation's satellite economy was precariously borne by a rickety oil monoculture. This observation is also consistent with Onimode's (1981) who indicated that the capital intensive mode of Nigeria's neo-colonial industrialisation, together with the orientation towards manufacturing consumer goods (particularly the domestic production of former imports) imply increased reliance on foreigners for imports of goods since virtually all of the spare parts for the production machineries are also imported.

\section{Latent Consequences of Development in Nigeria}

Development imbues a community or a nation state with a sense of sustainable worth, providing the collective citizenry with the infrastructural wherewithal to reach its potential by way of 
satisfying primary and secondary human needs. Much of the development effort in Nigeria has been curiously hinged on the proceeds from petroleum oil. The problems associated with the vagaries of the international spot and futures market for petroleum oil have also tended to undermine the pace and focus of development in Nigeria. When there is a rise in the market price of oil, as there was in the mid 1960s, there tend to be a rash of development activities. When there is a lull in the international market of petroleum oil there tend to be mass abandonment of development projects in Nigeria. Undue emphases on gigantic projects have not altogether translated into the expected economic benefits usually derivable from the economy of scale. Three major petroleum refineries have been built without actually increasing the nation's domestic capacity to meet fuel supply. Jike (1987: 91) highlighted the marked difference between potential capacity and the actual output of these refineries. This shortfall, according to Jike (1987) is largely due to the lack of vital spares that would guarantee the smooth functioning of the refineries. Because of this and other similar problems, local demand for petroleum products still outstrips supplies. In the last five years, especially during the present democratic dispensation, the refineries have virtually not functioned and petroleum oil has had to be imported at prohibitive costs with untold consequences both for industrial relations practice and for the welfare of the citizenry. The result of a large scale infrastructural decay and a development agenda without a clear focus has been widespread poverty while attempting to conceptualise poverty. Dike (1997: 158) noted that social science literature is replete with efforts by economists and social scientists to unravel the phenomenon of poverty "to date, no comprehensive theory of poverty has emerged rather, what we have are concepts for describing poverty, for explaining its various causes and hence suggesting solutions to its incidence. In what follows, we provide four broad conceptualisation of poverty;

a) Poverty as lack of access to basic needs/goals

b) Poverty as the result of lack of or impaired access to productive resources.

c) Poverty as the outcome of inefficient use of common resources.

d) Poverty as the result of 'exclusive mechanisms' Poverty is defined in terms of an annual income below which one becomes automatically poor.
Poverty is also said to be dependent on the income level of the society in which case, it is a relative concept. But whether or not we can define poverty correctly, we know what it is. We can see its effects on individuals, households and societies.

\section{The Challenge Posed by Poverty in the Niger Delta}

Table 1 clearly shows that except Bayelsa State which has $44.3 \%$ of her population below the poverty line; all the core oil-producing Niger Delta States (viz. Akwa Ibom, Cross River, Delta, Edo, Rivers) have more than $50 \%$ of their population living below the poverty line. This figure is highest in Rivers State which has $77.3 \%$ of her population living below the poverty line. It is perhaps instructive to note that government has attempted severally to create intervention agencies such as OMPADEC and NDDC to ameliorate the poverty situation in the Niger-Delta.

In tandem with the position of the World Bank

Table 1: The percentage of the population below the poverty line in the Niger Delta States

\begin{tabular}{lrrrr}
\hline States & 1980 & 1985 & 1992 & 1996 \\
\hline Akwa Ibom & 10.2 & 41.9 & 45.5 & 66.9 \\
Bayelsa & 7.2 & 44.4 & 43.4 & 44.3 \\
Cross River & 10.2 & 41.9 & 45.5 & 66.0 \\
Delta & 19.8 & 52.4 & 33.9 & 56.1 \\
Edo & 19.8 & 52.4 & 33.9 & 56.1 \\
Rivers & 7.2 & 44.4 & 43.4 & 77.3 \\
\hline
\end{tabular}

Source: Federal Office of Statistics. Reproduced by National Poverty Eradication Programme June, 2001.

and the United Nations Development Programme, Van de Walle (1990) has argued that the satisfaction of basic needs is a practical way of alleviating the consequences of poverty. She opined that well-nourished and educated individuals obviously have higher standard of living than sick, hungry and ignorant ones. This is because the former are more productive and better able to respond to new opportunities. She, therefore, suggested involvement in human capital development and involvement of the poor in the growth process (Tella 1997: 78).

The Nigerian Economic Society annual conference was largely devoted to the problems of poverty alleviation yet as Tella (1997: 78) rightly noted "the poverty level has continued to deepen unabated in the succeeding two decades. The World Bank study on poverty in Nigeria actually 
identified poverty in rural communities as related to poor physical facilities, food insecurity, obsolete agricultural practices, poor nutritional values, little access to savings and credit, and general inability to meet basic needs. For urban communities, the problems were unemployment, underemployment, the inability to educate children due to high cost, inadequate diet, kitchens, irregular water supply and electricity as well as the inability to clothe oneself adequately by prevailing social standards.

The Federal Government has, over the years attempted to address the problems of poverty by charging specific institutions with the task of poverty alleviation. Some of the poverty alleviation institutions include the Directorate for Food, Roads and Rural Infrastructures (DFRRI) etc.

The National Poverty Eradication Programme has issued a detailed list of such interventionist institutions to include:

i. Nigerian Agricultural Co-operative and Rural Development Bank (NACRDB),

ii. Universal Basic Education (UBE),

iii. River Basin Development Authorities (RBDA),

iv. Small and Medium Industries Development Agency (SMIDA),

v. National Bank for Industry (NBI),

vi. National Electric Power Authority (NEPA),

vii. National Directorate of Employment (NDE),

viii. National Primary Health Care Development Agency (NPHCDA),

ix. Federal Mortgage Bank of Nigeria (FMBN),

X. National Centre for Women Development (NCWD),

xi. Raw Materials Research and Development Council (RMRDC),

xii. Nigerian Mining Corporation (NMC),

xiii. National Youth Service Corps (NYSC),

xiv. Urban Development Bank (UDB),

Xv. Environmental Sanitation Boards (ESB),

xvi. National Agency for Science and Engineering Infrastructures (NASENI),

xvii. Women and Youth Development Centres (WYDC),

xviii. Nigerian Telecommunications (NITEL),

xix. Agricultural Research Institutes (ARI),

xx. Centre for Management Development (CMD),

xxi. National Water Resources Institute (NWRI), xxii. Metallurgical Training Institute (MTI),

xxiii. Petroleum Training Institute (PTI),

xxiv. Maritime Academy of Nigeria (MAN),

xxv. National Metallurgical Development Centre (NMDC),

xxvi. National Institute for Pharmaceutical Research and Development (NIPRD),

xxvii. National Commission for Museum (NCM), xxviii. National Gallery of Arts (NGA),

xxix. National Film Institute (NFI),

xxx. Ajaokuta Steel Company Ltd.,

xxxi. Nigerian Tourism Development Corporation (NTDC),

xxxii. Energy Commission of Nigeria (ECN),

xxxiii. Population Activities Fund Agency (PAFA),

xxxiv. National Programme on Immunisation (NPI),

xxxv. National Inland Water Way Authority (NIWA),

xxxvi. Industrial Training Fund (ITF), and

xxxvii. Non-Governmental Organisations (NGOs)

Because of the pervasiveness of poverty and the myriad social consequences of this scourge, government is determined to adopt a multidimensional approach to contain the spread of poverty in Nigeria. To this end, the government established the National Poverty Eradication Council (NAPEC) to co-ordinate the poverty reduction related activities of all the relevant ministries, parastatals and agencies. According to NAPEC's official bulletin, NAPEC is mandated to ensure that the wide range of activities are centrally planned and co-ordinated to complement one another so that the objectives of policy continuity and sustainability are achieved (NAPEP Bulletin June 2001).

The Poverty Alleviation Programme has not actually achieved the desired outcome. As Tella (1997: 79) rightly concurred with Salop (1992), the causes and solution to poverty go beyond macroeconomics and efficiency pricing. T he framework must therefore incorporate the behavioural context in which poverty persists in a particular setting. To this end, it is essential to understand the motivations and constraints of poor men and women, potential employers, providers of credit, and landlords, in (policy formulating) and evaluating the impact of policies, programmes, and projects.

The failure of Nigeria's poverty alleviation programme may not altogether be unconnected with the illustration in the Paradox of Poverty 
(1975 co-edited by Epstein) which examined poverty in relation to population growth.

Dube (1955) wrote of the widening gap between the rich and the poor in rural India, where he stressed the need to use a relative concept of poverty. According to Dube (1955), no universal index of poverty has been evolved, nor does this seem possible. Dube is critical of how the benefits of the new agricultural technology go primarily to the rich and not-so-rich; the poor get little or nothing. He also criticises the proposals for greater investments, improved health and the spread of education. He points out that higher investment, improved health and better education will not remove poverty (Epstein and Jackson 1975: 76; Castro et al. 1981: 420). This is also true of the Poverty Alleviation Programme in Nigeria which has wittingly or unwittingly widened the gulf between the rich and the poor. Even though the programme is supposedly tied up with specific projects that will empower the poor to lead a worthwhile life, in almost every situation money meant to alleviate poverty has been deployed to promote and sustain political party patronage and loyalty.

\section{Socio-economic Impact of Oil Production in the Niger Delta}

Industrial development by whatever criteria goes with corollary damage to the environment, social structure and social relationships. Since the discovery of petroleum oil by Shell in Oloibiri in 1958 and the subsequent flurry of prospecting activities by other multinational companies, much damage has been done to both the natural and the built environment in Nigeria. The natural environment has been severally breached by the deleterious consequences of oil exploration. Flora and fauna have been adversely affected, cash and subsistent crops have had more than a fair share of defoliation as a result of incessant oil spillage and the attendant toxicity of the soil.

As a consequence of the foregoing, the food chain has been partially truncated by hybrid crops that are a caricature of their former selves. Thus, yam tubers have become unusually small and even sweet varieties of yam have become everything but sweet. Aquatic life has not fared much better. Some species of fish have migrated and others have become virtually extinct as a result of oil spillage and industrial effluents that are wantonly disposed in mangrove swamps and fresh waters across the Niger-Delta.
Part of the problems of the impact of oil and gas on the natural environment is also transposed to the built environment in several forms. For example, it has been empirically established that corrugated iron sheets age much faster and depreciate more rapidly in the Niger-Delta than in other parts of Nigeria as a result of gas flaring.

Apart from the sad fact that oil exploration and the accruing revenue has not stimulated substantial economic growth and improved the standard of living of the people, it may be pertinent to highlight, as has been done graphically in figure 1 , how oil exploration and production have adversely affected every facet of life of the Niger Delta peoples. Petroleum Exploratron/ production has severe impact both on the natural as well as the built environment. In the natural environment there is overwhelming damage to both flora and fauna. There is a pervasive defoliation of leaves and plants and agricultural plants tend to become stunted. This of course has grave cost implica-tions for the food that is available in the market. This is also true of aquatic life which becomes endangered as a result of incessant spillages which pollutes fresh waters, swamps and the water table in the Niger Delta. The entire ecology can actually become truncated as wild life and rare species of birds are forced to migrate to relatively more clement environments.

The impact of oil and gas production on economic trees in the Niger-Delta has not been quantified but we make bold to say that incalculable damage is being done to economic trees in the Niger-Delta as a result of intermittent oil spillage and gas flaring.

\section{Oil and Gas Production Impact on the Built Environment}

Following the Eket oil spillage, the World Council of Mayors was prompted to undertake an environmental tour of Akwa Ibom in 2002 with a scathing condemnation of the ambivalent environmental policy of Mobile Exxon in Nigeria (Jike 2004). Almost across the length and breadth of the Niger-Delta, the impact of oil and gas on the built environment is quite evident in the discolouration of corrugated iron sheets by constant gas flaring. This also means as Eket House Owners Association asserted (and corroborated by World Council of Mayors) that the life span of roofing material in the Niger Delta is relatively shorter than in any other part of the larger Nigerian 


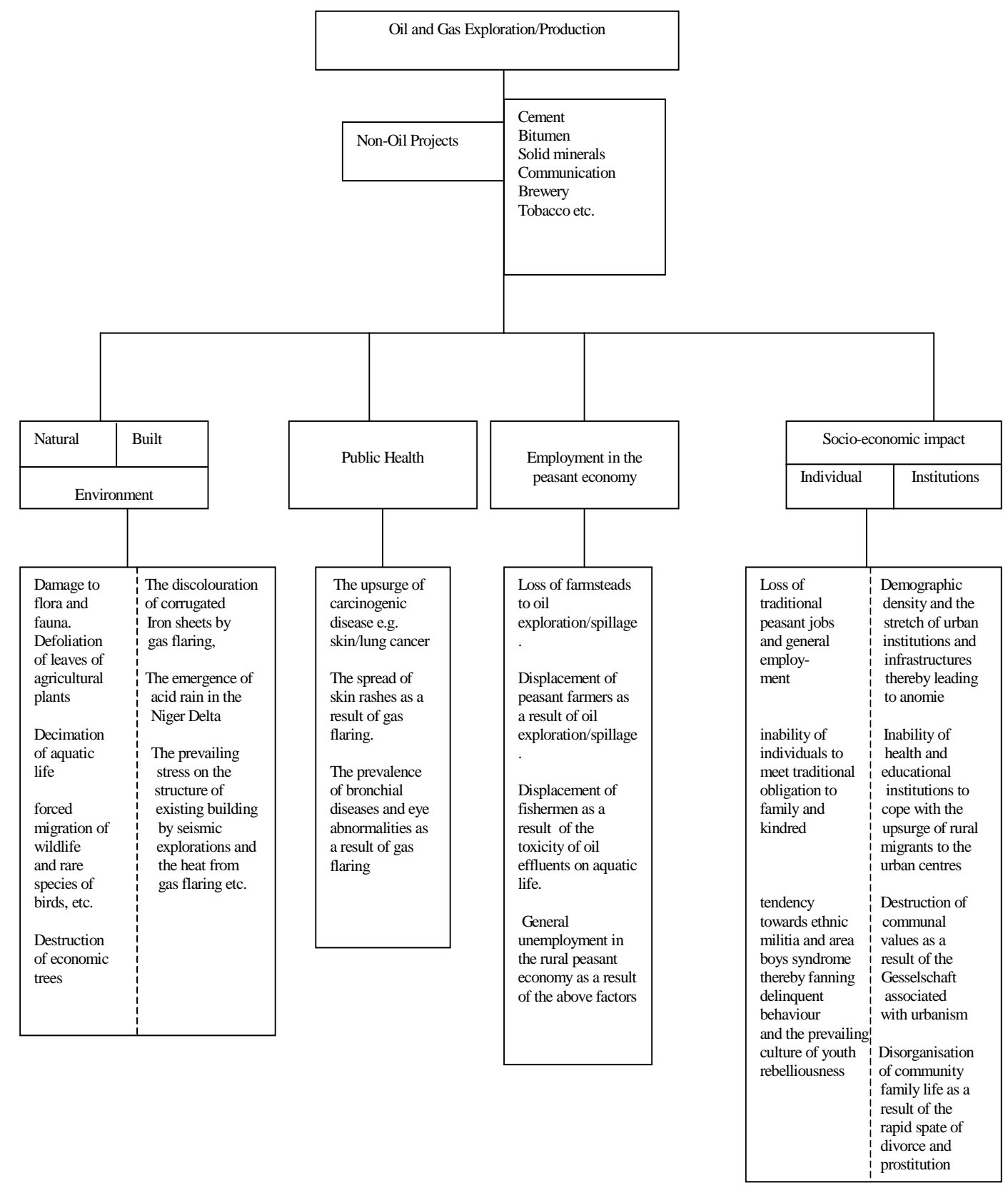

Fig. 1. How oil exploration and production have adversely affected every facet of life of the Niger Delta peoples. 
polity. Apart from the wholesale impairment of roofing material as a result of the frequent deluge of acid rain which is part-consequence of gas flaring, the seismic explo-sions and vibrations in the course of oil explora-tions create ample stress for existing structures in the built environment. At the slightest gale or tempest buildings begin to collapse as was the case this year (2004) when the National Assembly had to pass a resolution to send relief material to Delta State

\section{Oil and Gas Production Impact on Public Health}

The Warri Women Protesters in 2001 who besieged the headquarters of Shell Petroleum Development Company and Chevron clearly highlighted the deleterious impact of oil exploration on public health. The pubic health implications of oil spillage, especially gas flaring for the inhabitants of the Niger-Delta, have not been empirically systematised. However, the preliminary survey by Akoroda (2000) indicated that an emergent trend of carcinogenic diseases in the Niger Delta is traceable to the exposure of these people to the radioactive elements of gas flaring. These people suffer respiratory diseases, which are a consequence of long exposure to gas flaring (Jike 2004: 692). There is an apparent upsurge of carcinogenic diseases e.g. skin/lung cancer in the Niger Delta. Skin rashes are also very widespread in this area. The leaders of the Warri Women Protest of 2001 quite rightly traced the prevalence of bronchial diseases and eye abnormalities to unrestrained gas flaring by oil companies in the Niger Delta. The pressure on public health by gas flaring creates avoidable distortions on the health care delivery system, shifting sorely needed resources from areas of maximum need to areas of minimum need.

\section{Oil and Gas Production and the Problems of Unemployment in the Niger-Delta}

Perhaps, it is the greatest paradox of all time that the Niger Delta which produces the wealth of the nation also has more than fifty percent of its population living below the poverty line. This says a lot about the employment situation as well as the prospects for economic empowerment or collective enablement in the region. It is not reassuring to note that corporate organisations have not formulated contingency plans to extend the precept of social responsibility to host communities by way of training progra-mmes and other schemes to empower and enhance the prospects of youths in the host communities to participate in the mainstream of the economy. As it stands, the advent of oil production in the Niger Delta is a straightforward zero sum game, where the gain of oil companies and the Federal Government by way of equity, is the loss of indigenous peoples in the host communities by way of loss of farmsteads.

Loss of farmsteads to oil exploration/ spillage, the displacement of peasant farmers as a result of oil exploration/spillage and the displacement of fishermen as a result of the toxicity of oil effluents on aquatic life altogether provoked general unemployment in the rural peasant economy and the incipient informal economy in several metropolitan centres in the Niger Delta.

Widespread unemployment has implications for the sanctity of life and general security in the Niger Delta. The loss of traditional peasant holdings and ancillary jobs provoked a chain of psychological trauma for several individuals who are no longer able to meet traditional obligations. These perceptions of deprivations tend to coalesce into a general level of class or status consciousness which crystallise around an ethnic pivot in the form of ethnic militia to forcefully press for a change.

\section{The Assertiveness of Youth in the Niger-Delta}

The foregoing scenario has been highlighted rather succinctly by Jike (2002b: 13) who indicated that, the distribution of resources is skewed in favour of the dominant ethnic groups in Nigeria. The perception of injustice and inequity is rife especially among minority ethnic groups who have formed several militia groups to resist the plunderous drive of the federal government and its multinational allies. In this regard, mention must be made of the Niger-Delta area which has become the hotbed of youth activism and rebelliousness.

With an economic base that is largely uprooted by the operational activities of oil companies, the Niger Delta youth has very little option than to be assertive about his deprived condition. The once timid indigenous village youth or community elder have become utterly assertive and active in community affairs. The youths, especially, have made extra effort to ensure the compliance of multinational oil companies with standardised 
operational prac-tices in both the up and down stream facets of the oil industry.

Youths in several host communities have begun earnestly to enforce compliance with the social responsibility avowals of oil companies. We have begun to see infrastructures in Education, Health care delivery and other vital sectors of the nation's economy. All of these introspective reforms did not just happen overnight. They are, more or less, the product of a painstaking struggle by a mosaic of women, youths, and community elders to wrest collective community rights from gigantic multinational oil companies that often put pecuniary gains before communal welfare and sanctity. The Warri women protest of 2001 and the rapid spate of youth restiveness are illustrative examples of indigenous initiatives to checkmate the excesses of multinational companies pros-pecting for oil in the Niger-Delta. No doubt, youths in the Niger-Delta have often gone over the top in their anxiety to get even with oil companies who violate standard environmental practices. For example, we have heard gory tales of abduction of expatriate personnel, vandali-sation of oil pipelines or even murder of oil workers by irate youths. Conversely, we have also witnessed massive oil spillages and corollary environmental degradation that have permanently truncated and compromised the sanctity and fertility of local farmsteads. We have witnessed virtual decimation of aquatic life as a result of the forced migration of fish responding to the toxicity of effluents from the drilling chemicals of oil companies that are continually dumped in fresh water swamps in the Niger-Delta. The most desirable point of convergence and synergy is, perhaps, to activate the cord of social responsibility in multinational companies in order to meet inhabitants of the host communities at their point of needs. Especially to imbue the youths and other active members of the host community with the competencies and skills to play a useful role and make productive contributions to the main-stream of the nation's development. This, perhaps, is the point of departure and the central plank upon which the paper canvasses reciprocal empowerment of oil companies and host communities.

\section{Peace Building and Economic Empowerment in the Niger Delta}

Peacebuilding is a requisite precursor for individual economic growth and collective prosperity in the Niger Delta. For a long time conflict has been the bane of development in the Niger Delta. Oil Companies (OC) and Host Communities $(\mathrm{CH})$ have been engaged rather unwittingly in a zero sum game where the gain of OC translates rather diametrically as the loss of $\mathrm{HC}$ and vice verse. This conflict scenario is not typical of the Niger Delta. This is the consequence of the collective hope that has been repeatedly dashed. The discovery of the first oil well in 1956 in Oloibiri in Ogbia Local Government Area of present-day Bayelsa State held ample prospects for the transformation of the economic circumstances of the indigenous peoples and even beyond. The profit motive was paramount and preponderant in the priority of Shell D'Arcy, the company which was the precursor of Shell Petroleum Development Company. Paying a paltry royalty to the government of the day, Shell D'Arcy and its successor Shell Petroleum Development Company kept within the legally delimited and tolerable territorial bounds and carried on business as usual. The host communities in the halcyon early post-colonial days, were quite happy with having foreign oil prospectors within their midst without asking fundamental questions like operational practices or impact consequences of oil exploration. On both counts, times have changed. The youths are much more eager and better disposed to physically engage multinational oil companies to press for reforms and probable concessions that will improve their livelihood. This is the scenario against which the perennial conflict in the Niger-Delta should be viewed.

Conflict resolution in the Niger-Delta should, therefore, precede any worthwhile attempt at peacebuilding. Without a systematic mechanism for conflict resolution on a continuous basis, real or enduring peace will remain elusive. Peace cannot be bought by the protagonists in a conflict nor can financial compensation for the damage to the natural/built environment produce lasting peace. It might be useful to clarify our understanding of terms such as conflict, conflict resolution and peace or peace building.

As Francis (2004: 6) rightly noted, conflict, by definition, is an intrinsic and inevitable part of human existence, but that violent conflict is not inevitable and as such an anomaly. Conflict is defined as the pursuit of incompatible interests 
and goals by different groups. Armed conflict is the resort to the use of force and armed violence in the pursuit of incompatible and particular interests and goals. The worst forms of armed conflict include mass murder and genocide against unarmed civilians.

Kouassi (2004) has given on elaborate chronology of global conflict spanning several generations. According to him, the first generation of conflict is related to the management of the colonial heritage in the 1950s and in the first half of the 1960s. These conflicts concerned the legitimatisation of the nation-state and were different from those relating to the ushering in and the development of the cold war. Other flash points and new dimensions of conflict have appeared in Africa, with completely different characteristics from those of the previous era. The persistence and development of conflicts in Africa, despite the disappearance of the cold war show that the dynamics of these conflict calls for the design, analysis and redefinition of new methodologies for their resolution and the restoration of peace in Africa.

In his welcome address to the workshop on conflict resolution in Abuja March 8, 2004, Nigeria's former Minister of Education Prof. Fabian Osuji noted that "Africa has often been on the boil and stories that have been orchestrated from Africa have been stories of woes and conflicts". Ochoche (2002: 16) aptly indicated that the scourges of poverty and conflict remain the predominant global concern for developing countries. Deny (1995) has lamentably suggested that conflicts have cast a dark shadow over the prospects for a united, secure and prosperous Africa which we seek to create.

Here in Nigeria and especially in the Niger Delta, conflict has virtually truncated the prospects of achieving sustainable development. Sometimes conflict is overt as when a particular ethnic group slugs it out with a rival ethnic group over available resources in a particular area. Sometimes, conflict may be covert or even subdued as when youths in a particular locality begin to vandalise oil pipelines to express deep-seated conflict with the ruling government or oil companies.

\section{Conflict Resolution}

Ochoche (2002: 16) has rightly indicated that, Africa is faced with the challenge of establishing systems and structures that work responsibly well to reduce the frequency with which conflicts occur, and even when they occur, the ways and means of ensuring that human, material, institutional and infrastructural costs are kept low while ensuring that post-conflict peace building is made less costly and hazardous.

Francis (2004: 7) has located conflict resolution within the matrix of peace research. He notes that conflict theorists such as John Burton, Edward Azar and others have been influential in the development and conceptualisation of conflict resolution. Conflict resolution, thus, emerged as an alternative means of settling disputes (Fetherston 2000; Azar 1990; Burton 1990). When a conflict has been resolved and a mechanism is institutionalised to forestall a recurrence, one is implicitly promoting peace building. As Francis (2004: 7) succinctly noted,

Peacebuilding is about the attempt to overcome the structural, relational and cultural contradictions which lie at the root of conflict in order to underpin the processes of peacemaking. The debate on peacebuilding is between two schools. On the one hand, the 'top-down peacebuilding' referring to the conflict inter-vention efforts by powerful outsiders acting as experts, importing their own conceptions, and ignoring local cultures and capacities. And on the other hand, 'peacebuilding from below' which favours the respect, promotion and use of local human and sociocultural resources in building the peace.

The foregoing section has explored the ramifications of the Niger-Delta problems - in order to adopt a holistic approach to a worthwhile and lasting solution to the problem. There is a general tendency on the part of the government to think that there is a short cut or quick fix to the Niger-Delta conundrum. In the past, ad hoc committees, administrative or judicial panels have been constituted to address this problems but not much has been achieved. Perhaps, it may be pertinent to base any interventionist programme in the Niger-Delta on sound knowledge on the contending issues in this politically volatile environment. This position is congruent with the G8 Africa Action Plan which focuses specifically, on the need to expand knowledge by improving and promoting education and expanding digital opportunities, underlying that investing in education is critical to economic and social development in Africa and to provide Africans with greater opportunities for personal and collective advancement. 
It is curious that despite the intermittent crises in the Niger-Delta and the colossal loss of revenue/man hours the government which is eager to set up commissions of inquiry and judicial panels to examine any fresh eruption of conflict has not deemed it fit to provoke tertiary institutions in the Niger-Delta to engage in a syndicated in-depth scholarly inquiry on the remote and immediate causes of the Niger-Delta crises. Such a syndicated scholarly inquiry is long over due in order to provide a systematic resolution of the crises based on sound knowledge. It is important for the purpose of planning to have a realistic portrait of the profiles and tendencies that exist in the Niger-Delta. It is quite common to hear extension agents and development consultants recommending mass education as the single most potent panacea for the problems of the NigerDelta but as Buwai (2004: 6) rightly indicated, the development of civic education among the youths is a means, but not an end in itself.

The youths must be empowered with skills for employment to earn socially responsible living. This requires the development of technical and business skills among the youths that have gone through the civic reorientation. Provision of micro credit to enable the youths set up businesses is an integral part of this strategy.

It is quite revealing that the Federal Government in its desire to imbue youths with the requisite skill to make a living, approved the establishment of 47 Community Skills Development Centres (CSDC's) in 13 States and the FCT. Table 2 shows only $50 \%$ of the states of the NigerDelta (viz. Rivers, Delta and Edo) with such skill centres.

Table 2: Community Skills Development Centres (CSDC's) in 13 States and the FCT

\begin{tabular}{llc}
\hline S. No. & State & No. of Centres \\
\hline 1. & Lagos & 10 \\
2. & Kano & 5 \\
3. & Abia & 3 \\
4. & Anambra & 3 \\
5. & FCT & 3 \\
6. & Kaduna & 4 \\
7. & Sokoto & 2 \\
8. & Oyo & 2 \\
8. & Plateau & 2 \\
10. & Borno & 2 \\
11. & Rivers & 4 \\
12. & Delta & 3 \\
13. & Edo & 3 \\
13. & Benue & 2 \\
\hline
\end{tabular}

\section{Oil Community and the Host Synergy and Reciprocal Empowerment}

There is sufficient umbrage for oil companies and host communities to derive mutually inclusive benefits in the Niger-Delta if corporate policies and operational strategies proactively empathise the social conditions and objective reality of host communities corollary damage has been done to both oil companies and host communities. While the environment in host communities have been denigraded and desecrated with peasant farmers suffering loss of farmsteads and social displacement, oil companies have sometimes had their pipelines vandalised and flow stations seized. Kidnapping of expatriate personnel is also rife in many cities of the NigerDelta where oil companies are located.

Despite the long-term friction, the soured relationship between oil companies and host communities can be mended and bridges could be constructed to stimulate a much more condial and sustainable relationship between both stakeholders. This position tails back to our earlier treatise on the need for peace building because without enduring peace, oil production and distribution can not be sustained. Peace would encourage more productive activities that would stimulate wealth creation and generally uplift the standard of living of each individual and the citizenry. It is also expedient for us to know the psychological profile of the average Niger-Delta youth. This again will come out of a sustained scholarly research. There is much intervention by Government and the oil companies in the NigerDelta that is based on guess work and faulty assumptions. It is not necessarily correct that the average youth in the Niger-Delt is pugnacious or prone to propagating conflict at every available opportunity. It may not be true that those youths involved in the continuing fray in the Niger-Delta are all unemployed. It may not be true that deprivation or perception of inequity are the most potent factors that push the Niger-Delta youths into restiveness. While all these factors may independently influence the youth. There may also be moderating or intervening factors that may create an interaction effect that is yet to be envisaged. Our knowledge of the Niger-Delta youths and they are he is virtually enmeshed in conflict is yet to be systematised. We must earnestly begin a research sojourn to ultimately unmask the Niger-Delta youth. For example, what 
is his average age? What is his ethnic group identification? What is his age? What is his level of education? What is his employment status? Is he enlisted in a militia outfit? Is he a cult member? How does he currently meet his needs? What are his perceptions of the role of multi-national oil companies in his locality? These are question that will assist us as researcher and interventionist agents to draw up policies and programmes to integrate the Niger-Delta youth into the mainstream of development.

It is practically daunting for oil companies to provide jobs for all the youths in the Niger-Delta at a go. However, once a psychological profiling of the Niger-Delta youth is completed, then an Incremental Empowerment Initiative (IEI) could be started to make youths lead a decent life. Initially, the population of the Niger-Delta must be stratified for every section or strata to benefit from the proposed incremental empowerment initiative. Unemployed graduates will fall into a stratum, unschooled youths will belong in a different stratum. The stratification process will also recognise ethnic/religions group affiliation in order to ensure representativeness of every section of society. Once our knowledge of the psychological profile of the population is improved. We can now begin a systematic programme of education for empowerment. This could be divided into secondary education, adult education and higher education. Education is a critical ingredient for economic empowerment. The G8 Africa Action Plan has indicated that it is committed to supporting,

African countries in their efforts to improve the quality of education at all levels inter alia by giving special emphasis on teacher training initiatives, by supporting efforts to ensure equal access to education by women and girls, by providing scholarships and other educational support, and by working with African partner to increase assistance to Africa's research and higher education capacity in enhanced-partnership countries.

\section{REFERENCES}

Akoroda M 2000. Remediation Response in the Niger Delta. Paper Presented at a Seminar to Mark the Anniversary of Jesse Fire Disaster. Nigeria Institute of International Affairs Lagos August 15.

Azar E 1990. The Management of Protected Social Conflict: Theory and Case. Aldershot: Dartmouth Publishing.
Burton J 1990. Conflict: Resolution and Prevention. London: Macmillan.

Buwai G 2004. Youth Empowerment, Conflict Prevention and Poverty Eradication in Nigeria. Paper Presented at the University for Peace Curriculum Development Workshop for the West African Region.

Castro AP, Hakansson NT, Brokensha D 1981. Indicators of Rural Inequality. World Development, 9: 401-427.

Dike N 1997. Understanding the Multidimensional Nature of Poverty Selected Papers for the Nigerian Economic Society 1997 Annual Conference. Ibadan: Mag Press Ltd.

Dube SC 1955. Indian Village. London: Routledge and Kegan Paul.

Ember CR, Ember M 1977. Cultural Anthropology. London: Prentice Hall International Inc.

Epstein TS, Jackson D 1975. The Paradox of Poverty: Socio-economic Aspects of Population Growth. Delhi: Macmillan.

Eteng I 1981. Indigenisation for Lumpen-Bourgeois Development in Nigeria. In: O. Nnoli (Ed.): Path to Nigerian Development. Senegal, Dakar: Codesria Books Series, pp. 55-65

Fetherston AB 2000. From Conflict Resolution to Transformative Peacebuilding: Reflections from Croatia. Centre for Conflict Resolution, Department of Peace Studies. Bradford: University Press.

Francis DJ 2004. Definition, Conceptions and Debates on Peace and Conflict Studies in Africa: An Africanist Overview. Paper Presented at the University of Peace Africa Programme for Curriculum Development for the West African Region. Abuja, Nigeria March 812.

Jike VT 1987. US and THEM Syndrome - Social Determinants of Work Attitudes in Nigerian Urban Employment Sectors. Ph.D. Thesis, Unpublished. University of Bath, England.

Jike VT 2001. Niger-Delta Environment, Agricultural Disorientation and the most Probable Doomsday Scenario. Paper Presented at the Population Dynamics of Nigeria Conference. University of Lagos. October 15-17.

Jike VT 2002a. Environmental Disequilibrium and Contingent Responsibilities of Oil Companies and Host Communities in the Niger Delta. Paper Presented at the Health, Safety and Environment (HSE) Biennial International Conference on the Oil and Gas Industry in Nigeria, NICON Hilton Hotel, Abuja FCT.

Jike VT 2002b. Ethnic Militia and the Spectre of Social Organisation and Disunion in Contemporary Nigeria. In: VT Jike (Ed.): Ethnic Militia and Youth Rebelliousness in Contemporary Nigeria. Lagos: Niss Publications, pp. 11-16.

Jike VT 2004. Environmental Degradation, Social Disequilibrium, and the Dilemma of Sustainable Development in the Niger Delta of Nigeria. Journal of Black Studies, 34: 6868-701.

Kouassi K 2004. Design of Methodologies for the Resolution of Conflicts and the Restoration of Peace in Africa. Paper Presented at the University of Peace Africa Programme for Curriculum Development for the West African Region. Abuja, Nigeria March 812. 
Malinowski B 1939. The Group and the Individual in Functional Analysis. American Journal of Sociology, 5: 230-450.

Modo IVO 1995. A Handbook on Theories and Methods in Anthropology. Oyo: Dorand Publishers.

Ochoche SA 2002. ECOWAS in Conflict Prevention and Management in West Africa. Public Lecture Series No. 2, Department of Political Science, Faculty of Business and Social Sciences, University of Ilorin.

Olatubosun D 1975. Nigerian Neglected Rural Majority. Ibadan: Heinemann Educational Books.

Onimode B 1982. Imperialism and Underdevelopment in Nigeria: The Dialectics of Mass Poverty. London: Zed Press.

Pfeiffer J, Friendi J 1977. Anthropology: The Study of People. New York: Harper and Row Publishers.

Radcliffe-Brown AR 1952. Structures and Function in Primitive Society. London: Cohen West.
Salop J 1992. Reducing Poverty: Spreading the Word. Finance and Development, World Bank, Washington D.C.

Tella SA 1997. A Schema for Monitoring Poverty Alleviation Selected Papers for the 1997 Nigerian Economic Society Annual Conference. Ibadan: Mag Press Ltd.

Van de Walle D 1990. Policies for Reducing Poverty. Finance and Development Sept. World Bank.

Vosad 1999. Victims of Oil Spillage and Associated Disasters (VOSAD) Paper Presented at the Environmental Conservation and Remediation Inaugural Con-ference Nigeria Institute of International Affairs, August 18.

Wolf CP 1983. Keynote Address to the Official Opening Ceremony of Federal University of Technology, Yola, Nigeria Oct. 6 